\title{
長崎市における未発見被爆樹木の探索と保全上の課題
}

\section{Searching Process and Issues on conservation of Undiscovered A-bombed Trees in Nagasaki}

大脇 なぎさ* 鈴木 雅和** 王尾 和寿***

Nagisa OWAKI Masakazu SUZUKI Kazuhisa OHBI

\begin{abstract}
There are "A-bombed trees" in Nagasaki city, and they are the precious war heritage. The first purpose of this study is to clarify the problems of conservation and the current state of bombed trees in Nagasaki. We investigated on abnormal tree form in Nagasaki, and compared with results of the survey in Hiroshima. The second purpose is to develop a method to search for undiscovered bombed trees in Nagasaki, and to search for suspected of bombed trees. Number of bombed trees in Nagasaki is less than in Hiroshima. We guess that due to the topographical characteristics of the two cities, the forests that exist within a radius of $4.0 \mathrm{~km}$ were not entered into the recognition target. We superimposed the current aerial photograph, and photographs after bombing and before the bombing. To decrypts the green space that has continued from before the bombing to the current by visual observation, and extracted the location of the possibility of undiscovered bombed trees. And we investigated the location in Nagasaki. The results of the investigation, it became clear that the possibility of existence of undiscovered bomb trees is low in forest zone and high in shrines, temples, educational institutions and pubic facilities. Based on this investigation, we found the problem of the searching process and conservation of bombed trees and possibility of bombed trees in Nagasaki.
\end{abstract}

Keywords: Nagasaki, war heritage, abnormal tree form, a-bombed trees, aerial photograph キーワード：長崎，戦争遺産，樹形異常，被爆樹木，空中写真

\section{1. はじめに}

\section{(1) 研究の背景}

被爆 70 年を迎えて被爆関連の報道が増える中で, 被爆樹木に関 する既往研究・新規研究発表の少なさは, 終戦直後からほとんど 変化がない。被爆樹木に関する既往研究は，ほぼ広島市に限られ 1)，長崎市におけるそれはさらに少なく，長崎における被爆樹木 の実態が把握されていない。被爆樹木とは原子爆弾により被害を 受けた樹木を指す。

長崎市では長崎市被爆建造物等の取り扱い基淮 ${ }^{2)}$ が平成 10 年 に施行され，それに定められた調査，保存，活用方法に基づき， 被爆樹木がランク付けされて認定されている。現在, 長崎市には, 爆心地から半径約 $4 \mathrm{~km}$ 以内, 32 力所，約 35 本の被爆樹木が認定 されている。それに対し，広島市では爆心地から半径約 $2 \mathrm{~km}$ 以内 に, 55 力所約 170 本の被爆樹木が認定されている。両都市におい て被爆樹木に関する共通の研究は無く, 両都市での保全・認定・ 樹形異常等の実態を把握することは今後被爆樹木を被爆遺産とし て保全していく際に両都市での共通認識として必要である。

\section{(2) 本研究の目的亡意義}

本研究の目的は, 既往研究 ${ }^{1)}$ で明らかになった被爆樹木の特徵 を踏まえ, 長崎市の被爆樹木の外形調査や, 文献調査, ヒアリン グ等により長崎市の被爆樹木の実態を明らかにする事である。長 崎市での調査結果を広島市の被爆樹木の外形調査等と比較する事 により，両都市における被爆樹木の分布状況・認定状況・治療状 況の共通性や差異を把握する。また長崎市において被爆樹木と推 定される樹木を探索する方法論を開発し，実際に現地にて探索す る。長崎市において，これまで未探索であった山間部あるいは都 市部から被爆樹木と推定される樹木を発見することは, 被爆樹木 がこれまで治療を受けずとも健全に生存してきたことを示し，今 後の両都市での被爆樹木の認定や保全方策において，新たな知見 を得ることにつながるだろう。また，今後を認定する際の課題や 問題点を見いだす。

\section{2. 長崎市における被爆樹木の現状と広島市との比較}

\section{（1）長崎市と広島市の認定被爆樹木分布状況の違い}

図-1 は長崎市における認定被爆樹木の分布状況であり, 図一2 は広島市におけるそれである。両図を比較してみると，広島市に おいては, 爆心地から半径約 $2.5 \mathrm{~km}$ 以内にほぼ平均的に分布して いるのに対して，長崎市においてはその数が少ないことに加え， それらが直線的に分布している特徵がわかる。これは, 両市の地 形的な特性，つまり広島市は平坦で市街地が面的に広がっている のに対し，長崎市は南北を山で囲まれた細長い市街地形状のため であると思われる。被爆樹木を認定しようとする場合は，まず被 爆樹木を認知寸ることが前提である。広島市において被爆樹木が 市民の目に触れる機会は，爆心地から同心円的に方位に関わらず 平均的であるのに対し，長崎市においては，被爆樹木の認定が細 長い市街地に限られ，認定範囲の半径約 $4 \mathrm{~km}$ 以内においても，山 林内は認定対象となってはいなかったことが推測される。

\section{（2）認定状況の違い}

前述した通り, 長崎市では 32 力所の被爆樹木が認定されている。 被爆の痕跡の度合いから A D ランクに分けられている。 $\mathrm{A}$ ランク 14 力所, B ランク 7 カ所, C ランク 8 カ所, D ランク 3 カ所である。

長崎市では認定被爆樹木の登録件数が少ない上に，広島市の認 定被爆樹木が公共用地・学校・寺社であるのに対し, 長崎市は半 数が個人宅にある。個人所有の被爆樹木はその所有者により管理 される事になり, その存続が担保されているわけではない。今後 所有者の代替わり等により被爆樹木が無くなるという可能性があ るという問題点がある。広島市のように公共地に移植するという 方法も考慮する必要があろう。また被爆樹木の認定は樹木の個体 単位でなく, 複数の被爆樹木を含む場所の, 箇所単位である。被 爆樹木を保全する際に，箇所単位での登録では，同箇所にある一 本が枯死した場合，枯死した樹木の認知が行き届かない等，保全 するにあたり, 問題が生じる場合が有る。広島市では 2015 年に被 爆樹木全てに個体番号を付け，保全管理を行っている。

*筑波大学大学院人間総合科学研究科芸術専攻 **筑波大学芸術系 ***筑波大学芸術系 


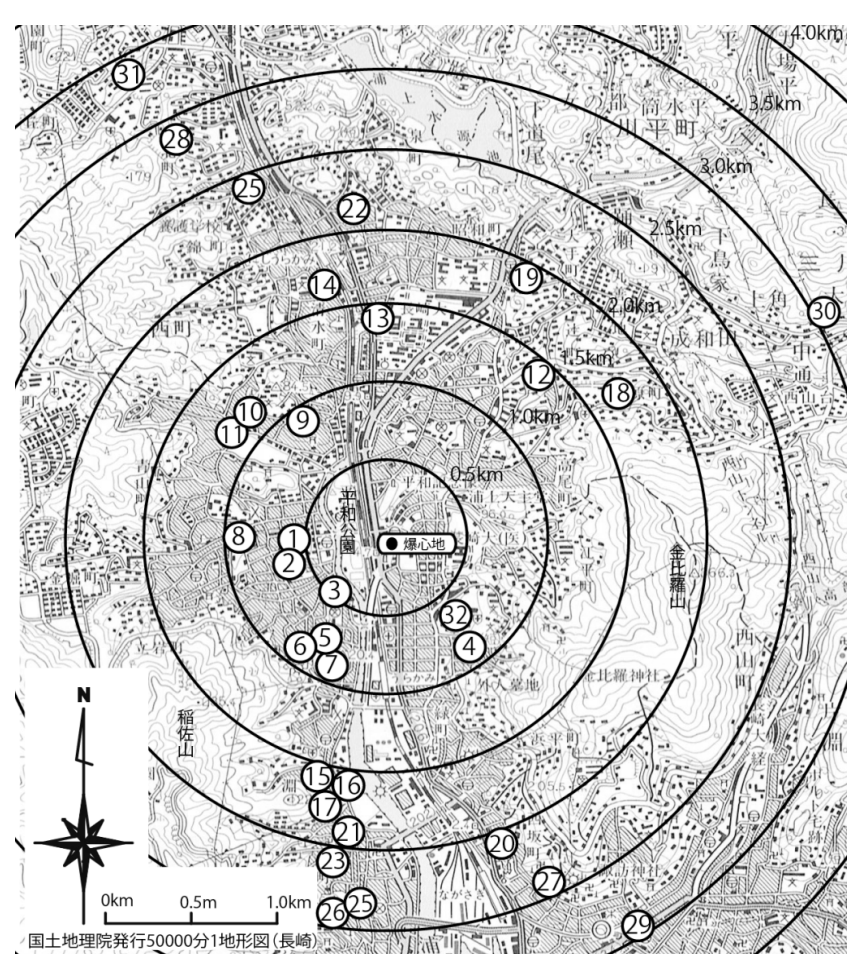

図一1 長崎市被爆樹木分布図

丸数字は長崎市の登録箇所番号であり, 同番号に複数の樹木か存在する

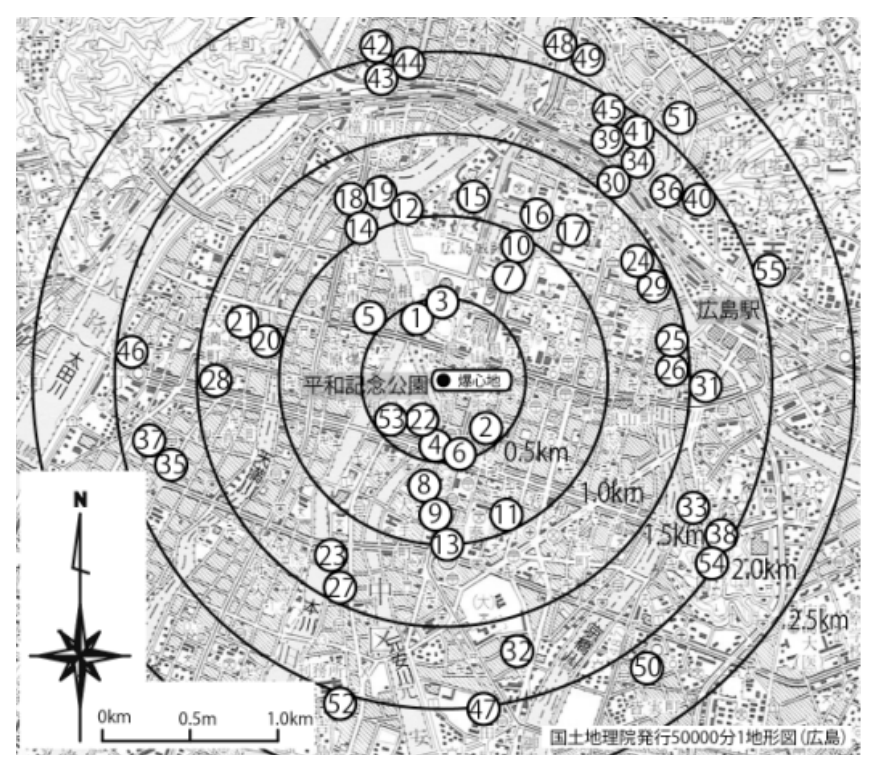

図一2 広島市被爆樹木分布図

丸数字は広島市の登録䇢所番号であり, 同番号に複数の樹木か存在する

表 -1 外形調査結果

\begin{tabular}{|c|c|c|c|c|c|c|c|c|c|c|c|c|c|}
\hline \multirow[b]{2}{*}{ 瞽木 } & \multirow[b]{2}{*}{ 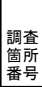 } & \multirow{2}{*}{ 调査地 } & \multirow{2}{*}{ 尌種 } & \multirow{2}{*}{$\begin{array}{c}\text { 爆心地 } \\
\text { 占の } \\
\text { 距離 (m) }\end{array}$} & \multicolumn{8}{|c|}{ 樹形異常の症状 } & \multirow{2}{*}{ 認 } \\
\hline & & & & & (1) & (2) & (3) & (4) & (5) & (6) & (7) & 8 & \\
\hline 1 & 1 & 桜町小 & ロガネモチ & 3,000 & 有 & 有 & 有 & \begin{tabular}{|c|c|c|} 
無 \\
\end{tabular} & 有 & 有 & 有 & 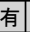 & 有 \\
\hline 2 & 2 & 稲佐小学校(枯死) & クスノキ & 1,900 & 有 & \begin{tabular}{|c|c|} 
無 \\
\end{tabular} & 有 & 無 & 有 & 有 & \begin{tabular}{|c|c|c|} 
無 \\
\end{tabular} & 無 & 有 \\
\hline 3 & 2 & 佐小学校 & クスノキ & 00 & 有 & 無 & 有 & 無 & 無 & 有 & 有 & 有 & 無 \\
\hline 4 & 3 & 淵神社(門脇) & クスノキ & 1,500 & 無 & 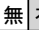 & 有 & 無 & 有 & 有 & 有 & 有 & 有 \\
\hline 5 & 3 & 淵神社(鳥居脇) & クスノキ &, 720 & 無 & 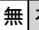 & 有 & 無 & 無 & 無 & 無 & 無 & 有 \\
\hline 6 & 10 & 崎医科大学 & クスノキ & 50 & 無 & 無: & 有 & 無 & 有 & 有 & 有 & 有 & 有 \\
\hline 7 & 5 & 諏訪神社脇道路 & クスノキ & 2,810 & 有 & 有 & 無 & 無 & 無 & 無 & 有 & 有 & \begin{tabular}{|c|c|c|} 
無 \\
\end{tabular} \\
\hline 8 & 5 & 諏訪神社脇道路 & クスノキ & 2,700 & 無 & 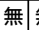 & 無 & 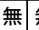 & 無 & 無 & 無 & 有 & \begin{tabular}{|c|c|c|c|} 
無 \\
\end{tabular} \\
\hline 9 & 6 & 長崎県立図書館裏 & クスノキ & 2,770 & 無 & 無 & 有 & 無 & 有 & 有 & 有 & 有 & \begin{tabular}{|c|c|l} 
無 \\
\end{tabular} \\
\hline 10 & 6 & 立山防空壕跡前䊽 & クスノキ & 2,680 & 無 & 無 & 有 & 無 万 & 有 & 有 & 無 & 有 & 無 \\
\hline 11 & 7 & 住吉神社 & クスノキ & 2,090 & 無 & 無 & 無 & 無 & 無 & 無 & 有 & 有 & 有 \\
\hline \multicolumn{14}{|c|}{$\begin{array}{l}\text { 樹形異常の症状(1)火傷跡(2)幹の亀裂(3)爆心地側の根の縮小(4)上コバエ(5)爆心地側の幹肌 } \\
\text { の萎縮(6爆心地反刘側の根の伸張 (7)爆心地反対側の幹肌の肥大幹斜 } \\
\end{array}$} \\
\hline \multicolumn{14}{|c|}{ (学名)クロガネモチ:llex rotunda クスノキ:Cinna } \\
\hline
\end{tabular}

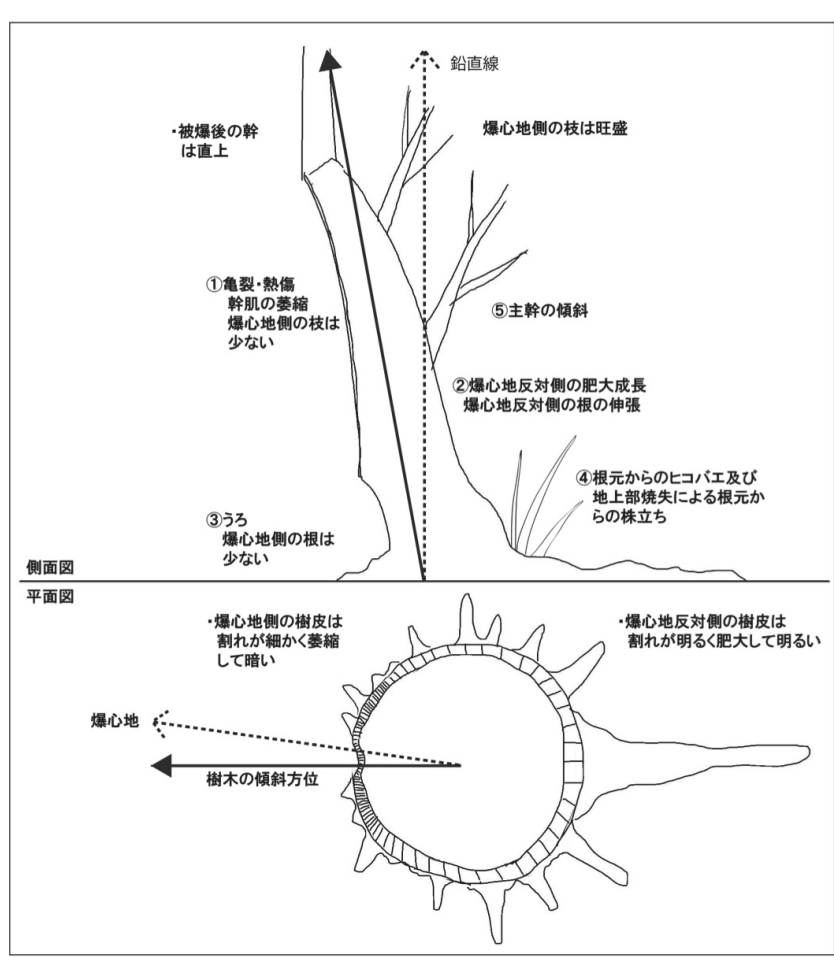

図-3 被爆樹木模式図

（3）広島市と長崎市における被爆樹木の治療方法の違い

両市における認定された被爆樹木に対する，行政を通じた樹木 医による治療処置について観察すると, 広島市においては樹木に 外科手術的処置を施すことは最小限として, 土畩条件を改良する ことや支柱を施すなどの治療を行っているのに対し，長崎市にお いては, 積極的に幹に樹脂・モルタルなどを詰めるなどの外科手 術的治療が行われていることが分かった。

\section{3. 研究手法}

\section{（1）典型的な被爆樹木の樹形と外形調査}

図-3 に，広島市における被爆樹木の観察 ${ }^{1)}$ に基づき，典型的 な被爆樹木の外形模式図を示した。本研究では 図一 3 に基づき, 被爆樹木の外形観察調査を行った。なお，樹齢・目通り周につい ては，長崎市の被爆樹木リストにも記載がなく，今回調査から省 いた。

広島市の被爆樹木の多くに見られる樹形異常は(1)熱線・放射線 及び周囲の建造物火災による火傷，萎縮。(2)障害を受けた反対側 の幹の肥大と根の伸張。(3)組織死滅による洞（うろ） (4)被爆後地 上部の焼失による根元からのひこばえあるいは主幹頂部からの株 立ち(5)主幹の傾斜，の5 項目が挙げられる。本研究において以上 5 項目に関する観察調査を行った。(2015 年 9 月 9-12の 4 日間)。

外形調査を行った樹木は現在長崎市が認定している被爆樹木 5 力所の 6 本, 空中写真の 2 時期比較と巨木調査により被爆樹木と 推定される樹木が存在しうる 4 力所の 5 本, 計 11 本を対象に行っ た。外形調査の結果, 調査地, 樹種, 爆心地からの距離, 樹形異 常の症状の有無, 認定の有無を表 -1 に示す。また, 図 -4 に調 査対象被爆樹木の位置を示寸。

爆心地から半径約 $2 \mathrm{~km}$ 以内の距離に存在する樹木全数に被爆の 影響による樹形異常が見られた。爆心地から半径約 $2 \mathrm{~km}$ 以上の距 離に存在する樹木（樹木番号 7 番を除く）は現在長崎市の認定被 爆樹木ではないが，火傷後や幹の亀裂等の目立った外傷は見られ ないものの, 爆心地側の幹肌の萎縮, 爆心地反対側の肥大成長な ど，被懪樹木に典型的な樹形異常が見られた。

\section{（2）未発見被爆樹木の存在可能性マッピングと探索}

本研究では, 爆心地を中心に半径約 $3 \mathrm{~km}$ を対象として, 原爆投 
下直後と現在の空中写真を使用し，樹林地の有無を比較すること により，被懪樹木と推定される樹木の存在可能性を探った。

広島市における被爆樹木認定の目安は半径約 $2 \mathrm{~km}$ であるが，半 径約 $2.5 \mathrm{~km}$ 付近に僅かであるが認定樹木が存在し, 長崎市におい ては半径約 $3 \mathrm{~km}$ 付近に認定樹木がある。これまでの広島・長崎市 での観察経験から半径約 $2.5 \mathrm{~km}$ を超えると被爆の痕跡が認めにく いことから，半径約 $3 \mathrm{~km}$ 以内を探索することで十分であると判断 した。

\section{i ）使用データと画像処理}

原爆投下直後の航空写真として, 1947 年および 1948 年の米軍 撮影による 6 枚を用いた（表一2）。これらは国土地理院提供によ るもので，1200dpi の TIFF 画像としてデジタル化されており，

（一財）日本地図センターを通じて購入した。また，現在の空中 写真として, 国土地理院の「地図・空中写真閲覧サービス」より, 2010 年撮影のカラーのデジタル画像 (400dpi JPEG 形式) 13 枚 をダウンロードして用いた。これら 2 時期の空中写真を GIS（地 理情報システム) に格納し，ジオリファレンス（幾何補正）を行 った。画像変換処理は主に 2 次多項式変換により，また参照する 既存地図は国土地理院提供の長崎市の基盤地図情報（道路縁，水 涯線, 建築物) を用い, 座標系は平面直角座標系 ( I 系) とした。 使用した GIS ソフトウェアは，ArcGIS10.2.2である。

表一2 使用データ概要

\begin{tabular}{|c|c|c|c|c|c|}
\hline 時期 & 撮影年月日 & $\begin{array}{c}\text { 撮影実施ま } \\
\text { たは計画機 } \\
\text { 関 }\end{array}$ & 撮影縮尺 & カラ一種別 & $\begin{array}{l}\text { 撮影時 } \\
\text { 写真種別 }\end{array}$ \\
\hline \multirow{6}{*}{$\begin{array}{l}\text { 投 } \\
\text { 下 } \\
\text { 直 } \\
\text { 後 }\end{array}$} & 1947/11/07(昭22) & 米軍 & $1 / 15979$ & モノクロ & アナログ \\
\hline & 1947/11/07(昭22) & 米軍 & $1 / 15979$ & モノクロ & アナログ \\
\hline & 1947/11/07(昭22) & 米軍 & $1 / 15979$ & モノクロ & アナログ \\
\hline & 1948/01/13(昭23) & 米軍 & $1 / 15772$ & モノクロ & アナログ \\
\hline & 1948/01/13(昭23) & 米軍 & $1 / 15772$ & モノクロ & アナログ \\
\hline & 1948/01/13(昭23) & 米軍 & $1 / 15772$ & モノクロ & アナログ \\
\hline \multirow{2}{*}{ 現在 } & $\begin{array}{c}\text { 2010/05/08(平22) } \\
\text { 4枚 }\end{array}$ & 国土地理院 & $1 / 10000$ & カラー & デジタル \\
\hline & $\begin{array}{c}\text { 2010/05/14(平22) } \\
\text { 9枚 }\end{array}$ & 国土地理院 & $1 / 10000$ & カラー & デジタル \\
\hline
\end{tabular}

ii）巨木調査マッピング

環境省の巨樹・巨木林調査結果 (第 6 回自然環境保全基礎調査) 3）を基に長崎市における巨木を爆心地から半径約 $3 \mathrm{~km}$ 圈内におい て，GIS 上で巨木の位置のポイントデータを作成し，現在の空中 写真と被爆後の空中写真重衫合わせ分析した。投下地点から半径 約 $3 \mathrm{~km}$ 圈内に 41 本, 地点としては 9 地点に巨木が有る。巨木リス 卜の中には現在長崎市が認定している被爆樹木も入っているため, それらを除いた樹木を調査対象とする。図一5に示した(1)(2)(3)(4) (5)は被爆樹木認定箇所である。しかし認定箇所の同敷地内には被 爆樹木に認定されていない巨樹が有り，被爆樹木と推定される樹 木があることが分かる。

iii）被爆樹木の存在可能性のある緑地マッピング

前述のデータ処理で得られた 2 時期の航空写真を用い，樹林地 の比較を行った。原爆投下直後に存在し，かつ現在も存在する樹 林地であれば，被爆樹木と推定される樹木が存在する可能性があ り，目視により該当する樹林地を抽出し，マッピングした。

マッピングした一部の空中写真を図一6 に示す。黒塗り部分が 被爆前後から現在まで緑地が継続している箇所である。

iv）被爆樹木と推定される樹木の探索

ii ），iii）でマッピングした緑地内から，被爆樹木と推定される樹 木を探索した。探索箇所を図－4 に示す。探索内容は緑地の所有 者からのヒアリング，また被爆後の空中写真等の閲覧により被爆 後の緑地の状況を把握し，樹木の外形調査を行った。
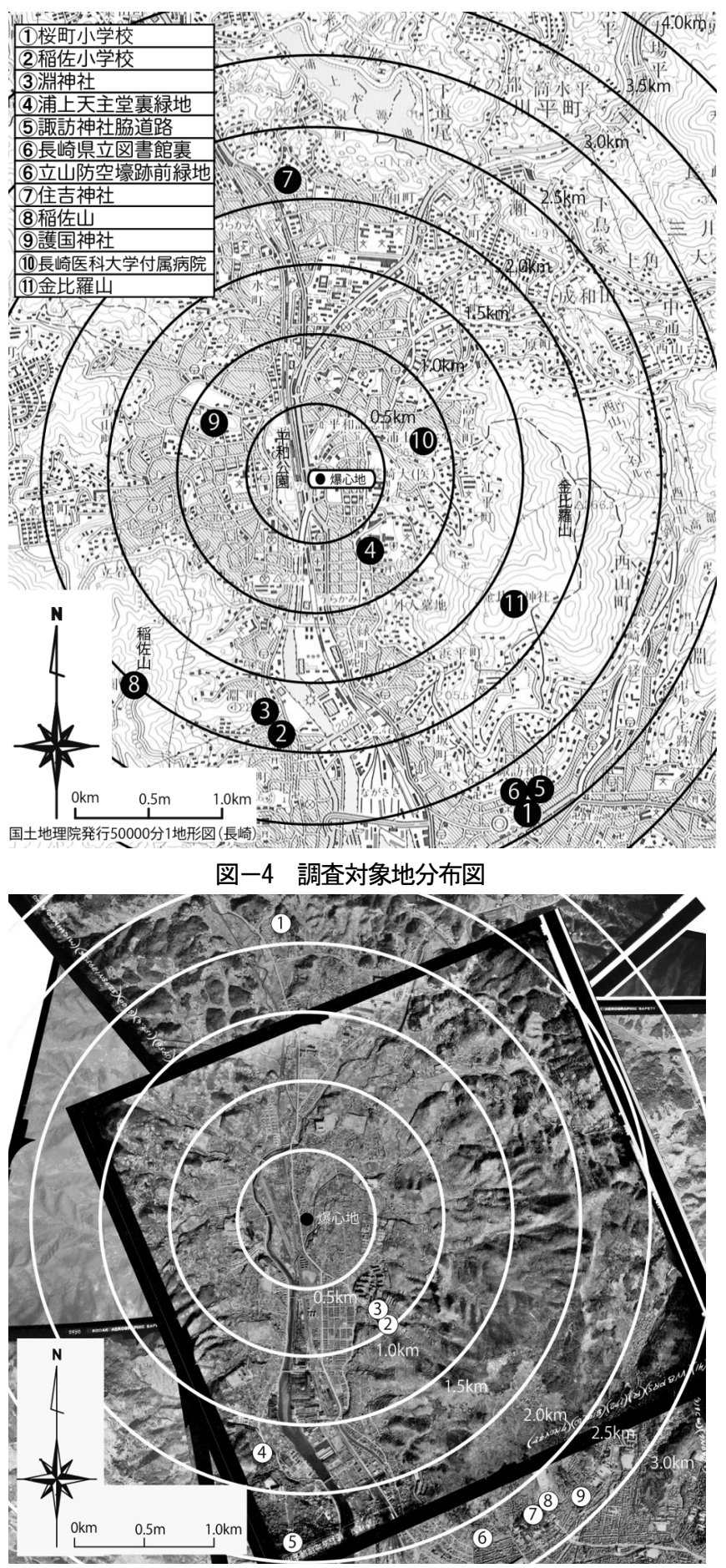

図一5 巨木マッピング図

丸数字は巨木認定箇所で同番号に複数の樹木か存在する

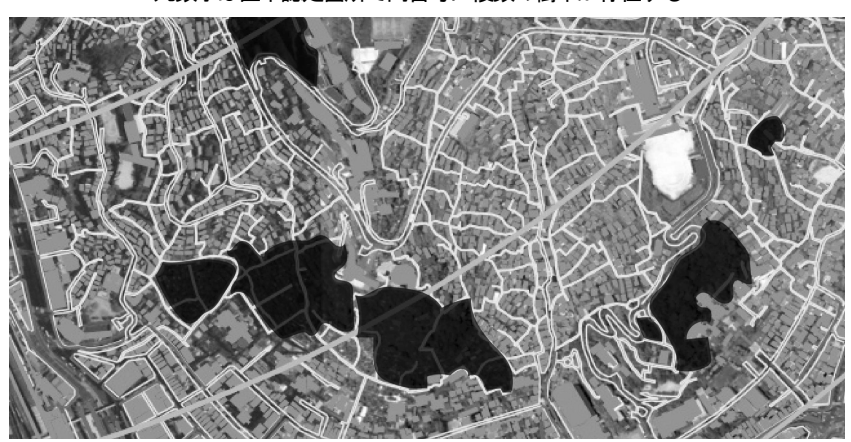

図一6 存在可能性マッピング図 黒塗り場所が継続緑地箇所 


\section{4. 調査結果の分析と考察}

\section{（1）広島市と長崎市における被爆樹木の樹形異常の比較}

広島市の被爆樹木と比較すると，長崎市では特徵として，被爆 の被害による外傷の程度が軽い傾向が見られた。広島市の外形調 査結果によると, 爆心地から半径約 $0.5 \mathrm{~km} \sim 1 \mathrm{~km}$ 圈内は半数が地上 部を全て焼失している。また，半径約 $1 \mathrm{~km} \sim 2 \mathrm{~km}$ 圈内においては， ほぼ全数に被爆による樹形異常や外傷がみられた。それに対し， 長崎市は, 半径約 $0.5 \mathrm{~m} \sim 1 \mathrm{~km}$ 圈内で地上部が全て焼失し, 再生し たものは少ない。また半径約 $1 \mathrm{~km} \sim 2 \mathrm{~km}$ 圈内の被爆樹木において, 被爆の痕跡はあるものの, その度合いが軽く，外傷や樹形異常の 該当数も少ないものが多い。半径約 $2 \mathrm{~km}$ を超えると目立った外傷 がほとんど見られなくなる。

被爆の痕跡は被爆樹木認定の際に重要な項目であり，長崎にお いて, 広島に比べ被爆の痕跡が少ないことが認定の本数差の要因 として考えられる。

\section{（2）被爆樹木と推定される樹木}

現地調査の結果，空中写真において被爆前から現在に至るま で継続した緑地内に有り，なおから巨木リストの箇所にも該当 する, 表-1 の樹木番号 7, 8, 9, 10 のように被爆樹木の典型的な 樹形異常を有寸る樹木（写真一 1,2 ) を発見したが，爆心地か ら半径約 $2 \mathrm{~km}$ 以上離孔ており，外傷の程度も少なく被爆時のも のという特定が難しく，当時の写真等での確認がとれなかった ため，被爆樹木であるとの確証には至らなかった。

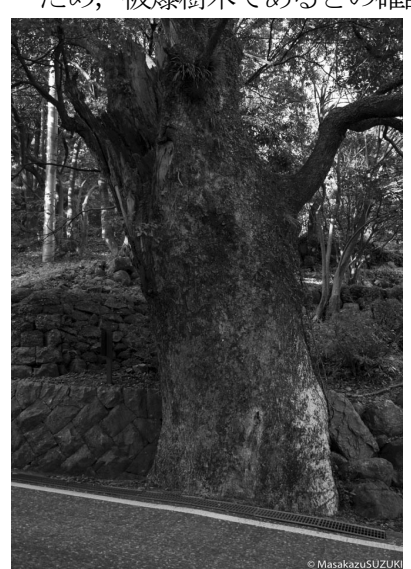

写真一 1 樹木番号 7

(諏訪神社脇道路のクスノキ)

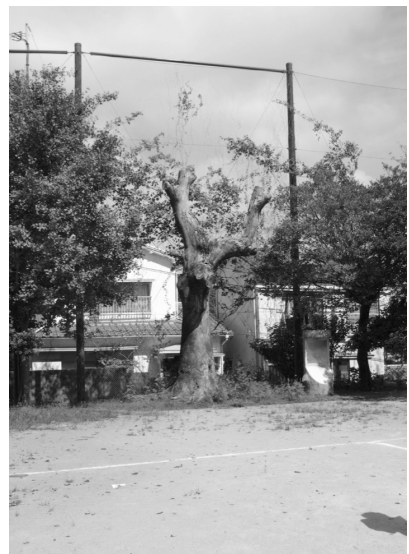

写真-3 樹木番号2

(枯死したクスノキ)

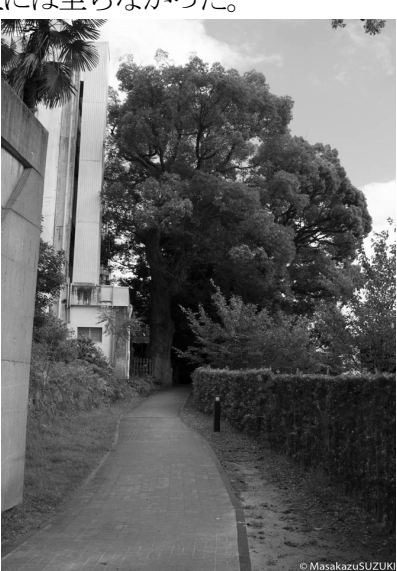

写真一2 樹木番号 9 （長崎県立図書館裏のクスノキ）

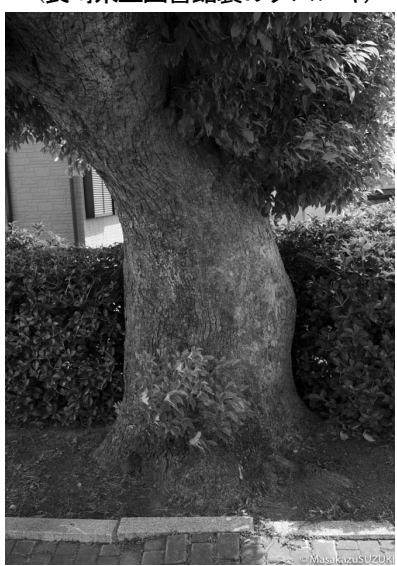

写真 -4 樹木番号3

(認定されていないクスノキ)
また，調査対象地 8,11 番の稲佐山や金比羅山の緑地は，ヒアリ ングや現地のパノラマ写真, 現地調査による植生の観察から, 被 爆後再生した杂隹木林，もしくは植林地等であり，樹齢100年以上の 被爆樹木が存続する植生の可能性が低いことが分かった。しかし， 調査対象地2番の稲佐小学校内において枯死したクスノキの他に
被爆樹木に該当する樹形異常を有する樹木を発見した（写真一 3, 4)。写真一-4の樹木は被爆前，被爆後の写真の中にも存在が認 められ，明らかに被爆樹木であるが，長崎市には認定されていな い。小学校長によると, 被爆の痕跡が認められないということが 理由ということであるが，外形調査の観察結果からは被爆の痕跡 が認められた。以上の考察から，被爆樹木と推定される樹木が存 在する場所は, 神社仏閣・教育施設・歴史的場所に可能性が高く, 被爆後再生した雑木林，もしくは植林地等の山間部には低いとい う事が分かった。

\section{5. まとめと今後の課題}

以上の結果から，長崎市では被爆樹木の外傷の度合いが広島に 比べて少ないことが明らかになった。被爆樹木を認定する際の認 定条件に，火傷など明らかな被爆の痕跡を認めずとも，図一 3 に 示したような被爆樹木の典型的な樹形異常が認められるものも積 極的に認定し，保全する必要がある。保全にあたり，人為的な治 療を行う際には, 両都市での治療法の違いを認識した上で, 今後 の被爆樹木の保全方法の考察が必要であり, 治療法の情報共有等 を行う必要があろう。また, 長崎市において被爆樹木と推定され る個体は，山間部には存在の可能性が低い事が明らかになった。 しかし，市街地の中に被爆樹木と推定される樹木が存在するとい う余地が有ることが分かった。

長崎市における被爆樹木と被爆樹木と推定される樹木に関する 課題は以下のとおりである。(1)現在の長崎の被爆樹木認定要項に, 被爆樹木が有する典型的な樹形異常を加え, 現在認定箇所の同敷 地内や 2 時期継続緑地にある被爆樹木と推定される樹木を詳細調 査する。(2)再調査により被爆樹木と推定される樹木を新たに認定 する際に，現在認定されている被爆樹木と同箇所に数本認定され る場合が予測される。被爆樹木を保全していくにあたり, 現在の 箇所単位での認定ではなく，個体識別を行い，個体番号をつけて 情報管理する必要がある。(3)本論文内の調査では長崎市の半径約 $3 \mathrm{~km}$ の緑地や山間部, 公共施設等の調査を網羅することが難しく, それら再調査や, 課題を解決する際に, 現地での組織的, 人的, 情報交流が不可欠である。(4)本論文内で被爆樹木と推定される樹 木を発見したが, 今後被爆樹木として確証するための技術・基準・ 認定等の方法論を見いだし，検証する必要がある。

謝辞 : 本稿執筆にあたり，資料提供をしていただいた長崎原爆資 料館の皆様, また樹木調査にご協力, 助言頂きました, 稲佐小学 校, 桜町小学校, 淵神社の皆様に, この場をお借りして厚く御礼 申し上げます。

\section{補注及び引用文献}

本研究において，現地において被爆樹木を特定できる最も信頼できる情 報として, 長崎市平和推進課が所有寸る被爆建造物等ランク一覧, 原子爆 弾被爆建造物位置図を利用した。

写真 1 4 は著者らが 2015/9/9-12 に撮影したものである。

1）大脇なぎさ，鈴木雅和，堀口力 (2014): 広島市における被爆樹木が爆心 地との位置関係において示す樹形異常 : ランドスケープ研究 77 (5), 627-632

2）長崎長崎市被爆建造物等の取り扱い基潐(1998)

3) 環境省: 第6 回自然環境保全基礎調查 (平成 11,12 年度) : 環境省ホームペ ージ〈http://www. biodic. go. jp/kiso/13/13_kyoju. html〉 2015 年 9 月 17 日参照 